\title{
The Dynamics of Local Democracy on Simultaneous Election in Semarang District
}

\author{
Martien Herna Susanti ${ }^{1 *}$ Setiajid $^{2}$ Anandha $^{3}$ \\ ${ }^{1,2,3}$ Faculty of Social Sciences, Universitas Negeri Semarang \\ *Corresponding author.email: martien@mail.unnes.ac.id
}

\begin{abstract}
This study aims to describe the implementation of simultaneous Pilkades (Village Headman Election) and the dynamics of local democracy in Semarang Regency 2018. The study applies a qualitative approach. Data were collected by in-depth interviews, then qualitatively analyzed. The results showed that one interesting phenomenon of the simultaneous Pilkades in Semarang Regency was the regulation on the quarantine of Headman candidates. The quarantine for the Headman candidates is unknown in the Village Law and is true agreement within the candidates so that the Pilkades runs conducive. This kind of regulation is very unique and full of local wisdom because it applies only in Semarang Regency. The dynamics of local democracy on simultaneous Headman election occurred after the enactment of the new rules about the participation of at least two candidates and a maximum of five Headman candidates. It brings out a new phenomenon, such as pseudo contestants of couples as candidates, besides their strategy to take advantages of all source of power they have especially their personal ability, wealth, nepotism network, up to money politics who participated on give colors in power struggle fighting on the village. Village head election is not only power struggle fighting, but also self-esteem, honor, and social symbols because a defeat in the Pilkades will be recorded and become a case study for social life in a village.
\end{abstract}

Keywords: Village Law, Local Democracy, Pilkades.

\section{INTRODUCTION}

The article describes the implementation and dynamics of democracy in simultaneous village head election at Semarang District in 2018. Village Head Election (Pilkades) simultaneously is the implementation of Law No. 6 of 2014 about the Village (Village Law). The Law Village not only aims to restore and develop original village autonomy through reaffirming village uniformity, but it implies social conservation which means protection of diversity, participation, democracy, and community empowerment suitable the socio-cultural values that develop within. Simultaneous village head elections are held simultaneously between villages in each regency/city in several waves a maximum of three times in six years.

Article 1 on the Regulation of the Minister of Home Affairs the Republic of Indonesia Number 112 of 2014 concerning Village Headman election, the village is a legal community unit that has its territorial boundaries that are authorized to regulate and manage their government affairs, the local community interest based on initiatives of the community, right of the origin, and/or traditional rights that are approved and respected on the government system of The Unitary State of the Republic of Indonesia. Village government is the village headman or called by another name assisted by village officials as an element of village administration.

The community has elected directly their village headman since Indonesia was not independent yet. It shows that the village has original autonomy which is the authority of the village administration in organizing and taking care of the local community based on the right of the origin and social values of the local community culture, but it must be held an administrative perspective of governments always up to date[11]. For all this time, village head election regulation that always changes since the Dutch era until the launch of the Village Law was not able to answer all interests and needs of the village community especially concerning the position of indigenous tribal peoples, democratization, diversity, and community participation. In the Dutch era, the winner of Pilkades was determined based on the 
longest supporters that marched in a field. As a consideration of the potential conflict, then that kind of system changed into a system of marked bamboo stick called biting that put into a special tube (bamboo represents the candidate) and placed in a closed chamber. After Indonesia's independence, Pilkades used a closed election on the voting booth using a paper in which drawn a photo and the name of the candidate for the village headman.

Regulations regarding village head elections, simultaneous village headman election (Pilkades) which requires the participation of at least two candidates and a maximum of five candidates have led to pseudo contestation by involving married couples as candidates as their strategies in utilizing their sources of personal abilities power, wealth, kinship networks, to the money politics that giving colors of a power struggle on the village level. Kartodirdjo state in village headman election (Pilkades), money politics as a tactic to win the election turned out of positive thing to increased public participation [4].

Changes in village regulations are not always positive, even village autonomy is a dramatic departure from the homogeneous model imposed under the New Order era when village apparatus and village structures were incorporated into administrative structures designed by the central government. There is a dependent tendency of village headman to the higher authorities power especially in making decisions that should always under government approval on districts and counties level. There is little space for innovation or aspirations of village communities, based on the interest of higher authorities. Thus the village administration extents were just miniature replicas of the central government interest because the decisions and policies have been determined from the top-level (Antlöv, 2003).

\section{RESEARCH METHODS}

The study uses a descriptive research design to obtain comprehensive, systematic, and in-depth information from the cases studied [3] in this case, is the dynamics of local democracy in the simultaneous Pilkades in Semarang Regency. The research sites included four villages in Semarang Regency which held the Pilkades simultaneously in 2018, those are Wonoyoso Village Pringapus District, Gondoriyo Village Bergas District, Kalikayen Village Timur Ungaran District, and Truko Village Bringin District Semarang Regency. The four villages were chosen because there was a prominent phenomenon in those villages. Village head election in Wonoyoso and Gondoriyo villages won by the new village headman defeated the incumbent. The elected village headman in Kaliyaken Village won by three votes differences. Truko village election was won by an incumbent with four votes differences. There is a quarantine for village headman candidates son each village. Research focuses include: (1) the simultaneous Pilkades in Semarang Regency in 2018; (2) the dynamics of local democracy in the simultaneous Pilkades in Semarang Regency. The sampling technique used purposive and the snowball of an incumbent village headman, village headman elected but not incumbent, the villagers who had the vote right, and Chief of Government of Rural and Village Community Empowerment Service Semarang District. Data collection technique through interviews and documentation. The data collected was tested for validity using data triangulation and triangulation methods. The data analysis technique used interactive qualitative analysis techniques.

\section{LOCAL DEMOCRACY}

Local democracy cannot be separated from decentralization policies. Even according to Putnam decentralization could foster participation and traditions at the local level. The citizen democratic participation has given high commitments and even the horizontal trust relationships, tolerance, cooperation, and solidarity called Putnam civic community[13]. According to Hanif Nurcholis, there are differences between education and political maturity of the Indonesian people and western which resulted in village-level democracy for up to two hundred years, did not have substantial democracy but procedural democracy. This is one of the reasons why villages cannot grow and develop healthy manner even though their democratic mechanism works ahead then direct democracy today [8].

Village election is truly competitive. Candidates must devote their network resources, intellectual creativity, physical effort, and material wealth to attract the villager support. There is a reciprocal relationship in the form of a patron-client between the village elite and the authorities which historically are colonial products that tend to be master-oriented rather than the community and impacted on the emergence of oligarchies, nepotism, even the village government authoritarianism[1]. Furthermore, Kevin O'Brien and $\mathrm{Li}$ Lianjiang described the village's independent governance as an effort to exchange limited democratic rights for people's compliance with state policies[6].

The village head election as the implementation form of local democracy not only community participation, but also the responsiveness of elected village headmen in fulfilling their campaign promises [16]. The Public can give a positive response (carrot) in the form of voting or vice versa give them punishment (stick) by not choosing anyone if the candidates unresponsive to the community's needs. Almost every Pilkades contestant covered their motives behind his candidacy by saying their 
aims solely to fulfill their duty and want to dedicate themselves to the community. Politicians speak about motives to pursue political careers, they rarely mention their interests such as the desire for power, prestige, and salary. Instead, they will refer to their devotion to society, their commitment and responsibility to the nation and state interests[2].

\section{SIMULTANEOUS HEADMAN ELECTION (PILKADES)}

The simultaneous Pilkades regulation as stated on the Village Law which requires the participation of at least two candidates and a maximum of five candidates resulting in contestation involving married couples as candidates. The participation of a husband or wife solely meets administrative requirements by eliminating competition, contrary to the opinion of Joseph A. Schumpeter which explains the method of democracy as an institutional arrangement to reach political decisions, in which individuals gain power through competitive struggles to get the votes [7].

\section{THE DYNAMICS OF VILLAGE HEAD ELECTION (PILKADES) IN INDONESIA}

The election of Village Heads is held simultaneously or can be in several periods of time. Article 3 further emphasizes that Pilkades will be held on the same day in all villages in the Regency / City area. Village headman election is the village people's sovereignty to elect village headman in which held directly, publicly, freely, confidential, honest, and fair, covering the stages of (1) preparation; (2) candidacy; (3) voting; and (4) determination [12]. The headman election is a democratic reflection at the local level, also an example of the uniqueness of local democracy in Indonesia. The democratic village headman elections were enlivened by the presence of botoh. Botoh is a term in Javanese and has the meaning "gambler". Botoh in the election of village heads has a significant role in winning candidates. Although the main goal of the botoh is gambling, it is one of the factors for a candidate's victory[5]. Winning with money bets is a top priority in carrying out its role. Botoh bets on the village headman, including providing political costs for the village headman to win, the reward is to get the economic benefits of gambling. While the village headman hoping to gain strength from botoh support through gambling and vote-buying practices [14].

\section{DYNAMICS OF LOCAL DEMOCRACY IN SIMULTANEOUS VILLAGE HEADMAN ELECTION (PILKADES) SEMARANG DISTRICT}

The election to the village of Semarang Regency is carried out based on regional Regulation Number 3 of 2015 Concerning the Election of Village Heads (Peraturan Daerah Kabupaten Semarang Nomor 3 tahun 2015 tentang Pemilihan Kepala Desa, 2015). Data shows that the average village headman that was elected both incumbent and not incumbent with an educational background of S1 (undergraduate) and D4 (applied undergraduate). This condition exceeds the provisions of the Village Law article 33 paragraph (d) which states that the lowest educated graduate for village headman candidate is junior high school or equivalent. Generally, the non-incumbent village headman elected does not have a kinship with the previous village headman. Based on interviews with nonincumbent village headman elected, those are village headman of Wonoyoso, Truko, Kalikayen does not have special preparation in those simultaneous village head election because there is no administration difference with the election before it except on the execution in the form of voting, the calculation is carried out in each Dusun, the required candidates at least two and a maximum of five, allowed people from out of the village to be candidates and the policy of quarantine for the village headman candidates.

Head of Village Administration Office of Community Development also recognizes the Semarang District preparations made by the Pilkades committee simultaneously at the village, sub-district, and district levels were held according to the schedule. Preparation is more mature and focused because coordination and preparation are easier. The coordination includes the institutions involved in the 2018 Pilkades, those are the Village Consultative Board (BPD), village committee, sub-district committee, district committee, Village Guidance Officer (Babinsa), Bhayangkara Community Security and Order Development (Babinkamtibmas), inspectorate, Dispermasdes, police, and Community Protection (Linmas).

Unique phenomenon simultaneous Pilkades in 2018 in Semarang district, the only one in Indonesia a quarantine policy of village headman. The village headman election (Pilkades) committee quarantined all the village headman candidates in a special place based on agreement. This policy is intended to maintain the security of each village territory during the voting process. The quarantine policy of the village headman candidate's aim is to anticipate things that are not desirable. Quarantine 
sites are based on mutual agreement, but most quarantine places are in the village offices. The village headman candidate who quarantined continues to use their right to vote at the polling station (TPS), which has been determined. The village headman candidates are also allowed to monitor the voting process at the polling station, but they must be guarded by the Community Protection officers. It was carried out to maintain the security as they monitor all activities of the village headman candidates start at $07.00 \mathrm{AM}$ until the vote count was completed or $01 \mathrm{PM}$. This agreement was proven to overcome the riot potency, even though there were quite vulnerable of a very small difference in the result of votes the Pilkades winners in two villages, those are in Kalikayen Village three votes and Truko Village is four votes. The participants accept their defeat with relief and sportive, although less satisfied at the beginning. It is understandable because Pilkades is not only a form of power struggle but self-esteem, honor, and social symbols after all defeat in the elections will be recorded and become a case study for social life patterns in the village. No mass gathering was also a factor of no riot, it also reduces the phenomenon of botoh which can affect the voter's voice.

The results of the simultaneous Pilkades analysis in Semarang district in 2018 proved to be more efficient and effective because: (1) in one Village head election could oversee the implementation of the Pilkades in more villages at the same time, (2) preparation is more mature and focused according to the schedule of the district (3) TPS placements (polling booth) on this simultaneous Pilkades residing in the sub-village had been proven improved voter participation, ( 4 ) the results is known faster because the calculation is performed on each sub-village, (5) reduce the potency of a riot between supporters, (6) minimizing the botoh gambling, and (7) proving that quarantine policy is a symbol of family and cooperation that is still maintained. There is hope given by the village headman candidate toward the next simultaneous Pilkades: (1) there are time and space needed by candidates to deliver their vision and mission to the community that also minimize the money politics practice, (2) there is more mature socialization towards the voter candidates so that Pilkades implemented in a transparent, honest and clean, dignified, directly, publicly, secretly and freely.

\section{CONCLUSION}

The uniqueness of simultaneous Pilkades at Semarang regency in 2018 and become the only one in Indonesia is the policy of quarantine the village headman candidate which has been proven to cope with the emergence of riot potency during the voting process. This quarantine does not state on the Regional Regulation and is only based on the agreement between the village headman election committee with the candidates. The quarantine policy does not eliminate the right of candidates to use their voting rights and the opportunity to monitor the voting process at polling stations. The agreement between the village headman candidates shows that the family ties and the spirit of cooperation are still strongly maintained as a form of social conservation of village communities in Semarang Regency.

\section{ACKNOWLEDGMENT}

The authors would like to thank the Head of the Institute for Research and Community Service (LP2M) Semarang State University, the Dean of the Faculty of Social Sciences who facilitated this research, the village head of Wonoyoso Village, Pringapus District, Gondoriyo Village, Bergas District, Kalikayen Village, Ungaran Timur District, and Truko Village, District Bringin Semarang Regency as research respondents who contributed to this research.

\section{REFERENCES}

[1] Aspinall, E., \& Mas'Udi, W. (2017). The 2017 local elections in Indonesia: Clientelism, programmatic politics, and social networks. Contemporary Southeast Asia, 39(3), 417-426. https://doi.org/10.1355/cs39-3a

[2] Beniers, K. J., \& Dur, R. (2007). Politicians' motivation, political culture, and electoral competition. International Tax and Public Finance, 14(1), 29-54. https://doi.org/10.1007/s10797-006-8878-y

[3] Creswell, J. W. (2015). Penelitian Kualitatif dan Desain Riset (Edisi 3) - Memilih di Antara Lima Pendekatan (3 ed.). Yogyakarta: Pusta.

[4] Fitriyah. (2015). POLITIKA, Vol. 6, No.2, Oktober 2015

$$
\text { 101. 6(2), 101-111. }
$$

[5] Hartati, A., Nafisa, A. Y., \& Hidayanti, T. T. (2019). Botoh dalam Pilkada: Studi Pola Kerja dan Transformasi Botoh dalam Pilkada Kudus 2018. Jurnal PolGov, I(1), 121. https://doi.org/10.22146/polgov.v1i1.48301

[6] Kevin $O$ 'Brien and Li Lianjiang, Rightful Resistance Kevin $O$ ' Brien and Li Lianjiang, Rightful Resistance in Rural China. (2016).

[7] Maskuruddin Hafidz, dkk. (2018). Fenomena calon tunggal Fenomena calon tunggal. 
Bawaslu, 1(14). Diambil dari https://www.bawaslu.go.id/sites/default/files/pu blikasi/5. Penelitian Calon Tunggal.pdf

[8] Nurcholis, H. (2013). Dua Ratus Tahun Praktek Demokrasi Desa, Potret Kegagalan Adopsi Demokrasi Barat.

[9] Peraturan Daerah Kabupaten Semarang Nomor 3 tahun 2015 tentang Pemilihan Kepala Desa. (2015). Diambil dari file:///C:/Users

[10] Peraturan Menteri Dalam Negeri Republik Indonesia Nomor 112 Tahun 2014 tentang Pemilihan Kepala Desa Peraturan Daerah Kabupaten Semarang Nomor 8 Tahun 2017 tentang Perubahan atas Peraturan Daerah Kabupaten Semarang Nomor 3 Tahun 2015 tentang Pemilihan Kep. (2014). Diambil dari https://www.panggungharjo.desa.id/wpcontent/uploads/2018/03/PERMENDAGRI-No.112-Tahun-2014-tentang-Pemilihan-KepalaDesa.pdf

[11] Peraturan Pemerintah Nomor 72 Tahun 2005 tentang Desa. (n.d.). Diambil dari http://binapemdes.kemendagri.go.id/uploads/gall ery/PP_No._72_Th_._2005_Ttg_._Desa_.pdf

[12] Permendagri 112 tahun 2014 tentang Pemilihan Kepala Desa. (2014).

[13] Putnam, R. (1993). “The prosperous community: Social capital and public life." The American Prospect, 4(13), 35-42.

[14] Romadhan, A., Khanifah, L. N., Sihidi, I. T., \& Kamil, M. (2019). the Role of Bossism in Practice of Gambling Election of Village Head in Batu City. 899-909. https://doi.org/10.32528/pi.v0i0.2552

[15] Shakya, M. (2006). Book Review: Politicising democracy: the new local politics of democratization. In Progress in Development Studies (Vol. https://doi.org/10.1177/146499340600600314

[16] Suyatno, S. (2016). Pemilihan Kepala Daerah (Pilkada) dan Tantangan Demokrasi Lokal di Indonesia. Politik Indonesia: Indonesian Political Science Review, 1(2), 212. https://doi.org/10.15294/jpi.v1i2.6586 